\title{
ARAHAN KEBIJAKAN PENGENDALIAN KONVERSI LAHAN SAWAH DI KOTA SOLOK
}

\author{
Guidance of Paddy Field Conversion Policy in Solok
}

Siska Nofita ${ }^{1}$, Santun R.P Sitorus ${ }^{2}$, Atang Sutandi ${ }^{3}$

Diterima: 7 Januari 2016 Disetujui: 19 Juli 2016

\begin{abstract}
Abstrak: Konversi lahan sawah terjadi seiring dengan pertumbuhan penduduk yang terus meningkat yang diikuti oleh peningkatan kebutuhan lahan untuk kegiatan non pertanian. Penelitian ini bertujuan untuk merumuskan arahan pengendalian konversi lahan sawah di Kota Solok. Analisis yang dilakukan adalah analisis skalogram dan analisis regresi stepwise untuk mengetahui faktorfaktor yang mempengaruhi konversi lahan sawah di Kota Solok. Lahan sawah di Kota Solok tahun 2004 - 2014 telah terkonversi 32,28 ha, terutama di Kecamatan Lubuk Sikarah dan gejala konversi ini meningkat tajam pada tahun 2015. Sebagian besar Kelurahan di Kota Solok berhierarki 1 kecuali Kelurahan IX Korong dengan hierarki 2 dan Kelurahan Laing berhierarki 3. Faktor-faktor yang mempengaruhi konversi lahan sawah di Kota Solok adalah Pajak Bumi dan Bangunan, pengurusan hak atas tanah (sertifikasi tanah), dan alokasi lahan untuk industri, alokasi lahan untuk pemukiman kepadatan rendah, alokasi lahan untuk pemukiman kepadatan tinggi, alokasi lahan untuk peribadatan, dan alokasi lahan untuk sawah pada Pola Ruang Kota Solok yang termuat dalam RTRW Kota Solok. Arahan Pengendalian Konversi lahan di Kota Solok adalah menaikkan pajak atas tanah nonpertanian, meningkatkan peran lembaga adat, tokoh masyarakat dan penyuluh pertanian, menetapkan zonasi kawasan di Kota Solok dengan menetapkan RDTR Kota Solok, penentuan dan penetapan Lahan Pertanian Pangan Berkelanjutan (LP2B) dan memperbaiki jaringan irigasi yang rusak.
\end{abstract}

Kata kunci: arahan pengendalian, sawah, konversi lahan sawah.

\begin{abstract}
Paddy field conversion occurs along with population growth followed by increased need for non-agricultural land. This research aims to formulate the direction control of paddy field conversion in Solok. Therefore it is necessary to analyze, they are scalogram analysis, and stepwise regression analysis. Paddy fields conversion in period of 2004-2014 in the Solok city 32,28 ha, mostly in the Lubuk Sikarah District. The threat of paddy fields conversion based of RTRW Solok city 2012-2031 is 403,60 ha $(41,55 \%)$. Most of the villages in Solok belong to Hierarchy 1 except IX Korong with hierarchy 2 and Laing with hierarchy 3. The factors affecting of paddy field conversion in Solok city is land and building tax, land tittling, and the allocation of land for industrial, low density residential, high density residential, worship, and paddy fields allocation in the RTRW. Control direction of paddy field conversion in Solok city is to raise taxes on non-agriculture land, increasing the role of traditional institutions, community leaders and agricultural extension, zoning by setting RDTR of Solok city, determination of food sustainable agricultural land (LP2B) and repair damaged irrigation networks.
\end{abstract}

Keywords: control directives, paddy fields, paddy field conversion.

\footnotetext{
${ }^{1}$ Dinas Pertanian Perikanan dan Kehutanan Kota Solok

${ }^{2}$ Program Studi Ilmu Perencanaan Wilayah, Sekolah Pascasarjana IPB
}

Korespondensi: siskayangmen@gmail.com 


\section{PENDAHULUAN}

Keberadaan lahan sawah sebagai penghasil beras sangat penting dalam memenuhi kebutuhan masyarakat terhadap pangan, namun hal ini sulit dipenuhi karena kebutuhan beras masyarakat yang semakin tinggi sejalan dengan pertumbuhan penduduk yang terus bertambah diiringi dengan kebutuhan lahan untuk kegiatan nonpertanian. Disisi lain, luas lahan yang tersedia tetap dan hal ini mengakibatkan lahan pertanian yang ada dikonversi untuk keperluan-keperluan nonpertanian tersebut. Irawan dan Friyatno (2002) dan Iqbal (2007) memaparkan bahwa konversi lahan terjadi seiring makin tinggi dan bertambahnya tekanan kebutuhan dan permintaan terhadap lahan, baik dari sektor pertanian maupun dari sektor nonpertanian akibat pertambahan penduduk dan kegiatan pembangunan.

Kota Solok merupakan kota yang dikenal sebagai Kota Beras dengan luas lahan sawah 1254 ha pada tahun 2004 (BPS, 2005) dan pada tahun 2014 menjadi 876 ha (BPS, 2015), dimana terjadi penyusutan 378 ha. Penyusutan lahan sawah di Kota Solok didominasi oleh pembangunan perumahan dan fasilitas umum dan bangunan lainnya. Peraturan Daerah Kota Solok No 13 Tahun 2012 tentang RTRW Kota Solok tahun 2012-2031 mengalokasikan kawasan budidaya tanaman pangan dengan luas 490,06 ha. Apabila dibandingkan dengan luas lahan sawah kota Solok pada tahun 2014 dari data BPS yaitu 876 ha, dengan RTRW tersebut maka terdapat peluang untuk konversi lahan sawah di Kota Solok.

Menurut Djajus (2009) perubahan luas lahan sawah disebabkan oleh alih fungsi lahan, khususnya dari lahan pertanian ke lahan nonpertaniaan, biasanya berubah menjadi pemukiman atau usaha ekonomi lainnya. Alih fungsi lahan masih terus terjadi karena semakin meningkatnya jumlah penduduk dan lemahnya kesadaran masyarakat dalam pemanfaatan lahan.Peningkatan jumlah penduduk Kota Solok juga mengakibatkan meningkatnya kebutuhan lahan untuk nonpertanian, sehingga konsekuensinya terjadi konversi lahan sawah untuk kebutuhan tersebut. Berkurangnya luas lahan sawah di kota Solok juga berdampak terhadap turunnya produksi padi di kota ini. Pada tahun 2012 telah terjadi penurunan produksi beras sebesar 8,3\% dibandingkan dengan tahun 2011. Penurunan produksi padi di Kota Solok dikhawatirkan nantinya akan mempengaruhi keberadaan Kota Solok sebagai Kota beras. Pada satu tahun terakhir, konversi lahan di Kota Solok meningkat lebih tinggi dari tahun-tahun sebelumnya. Hal ini terlihat dengan semakin banyaknya pemukiman dan pertokoan yang tersebar di daerah ini. Konversi lahan sawah ini bisa tidak terkendali karena belum adanya peraturan daerah mengenai alih fungsi lahan sawah di Kota Solok.

Sejalan dengan perubahan struktur perekonomian yang merupakan ciri perkembangan suatu negara atau daerah, kebutuhan lahan untuk kegiatan nonpertanian akan mengalami peningkatan dari tahun ke tahun. Kecenderungan tersebut menyebabkan konversi lahan pertanian sulit dihindari dengan kata lain setiap tahunnya pasti terjadi konversi lahan. Luas konversi lahan tersebut setiap tahunnya akan semakin besar karena konversi lahan pertanian umumnya menular. Dengan kata lain, sekali konversi lahan terjadi di suatu lokasi maka luas lahan yang akan dikonversi di lokasi tersebut akan semakin besar akibat konversi lahan ikutan yang terjadi di lokasi sekitarnya (Hidayat, 2012). Menurut Santosa et al. (2011), alih fungsi lahan sawah dari tahun ke tahun terus meningkat, dan dikhawatirkan akan mengancam ketahanan pangan beras dan lahan yang telah dialihfungsikan tidak bisa dikembalikan menjadi lahan sawah seperti semula, sedangkan pencetakan lahan sawah terkendala oleh biaya tinggi dan waktu yang lama.

Pada satu tahun terakhir, konversi lahan sawah di Kota Solok meningkat dengan drastis. Konversi lahan sawah ini terlihat jelas dengan banyaknya bermunculan pemukiman- 
pemukiman baru pada satu tahun terakhir, seperti di Kelurahan Simpang Rumbio, Kelurahan Tanah Garam dan Kampai Tabu Karambia (KTK). Melihat kenyataan ini apabila konversi lahan sawah di Kota Solok tidak dikendalikan maka keberadaan Kota Solok sebagai kota beras akan terancam, dimana sampai saat ini Kota Solok merupakan kota yang mengalami surplus beras namun untuk masa yang akan datang dikhawatirkan akan terjadi kondisi yang sebaliknya, Kota Solok akan mengalami defisit beras dan harus mendatangkan beras dari luar Kota Solok.

Tujuan dari penelitian ini adalah: (1) Mengidentifikasi perubahan penggunaan lahan sawah di Kota Solok, (2) Mengetahui faktor penyebab alih fungsi lahan sawah di Kota Solok dan (3) Merumuskan arahan pengendalian alih fungsi lahan sawah menjadi nonpertanian di Kota Solok

\section{METODE}

\section{Lokasi dan Waktu Penelitian}

Penelitian ini dilaksanakan pada bulan April sampai November 2015 di Kota Solok meliputi Kecamatan Lubuk Sikarah dengan tujuh kelurahan dan Kecamatan Tanjung Harapan dengan enam kelurahan(Gambar 1). Kota Solok secara geografis terletak pada posisi 0॰32” LU - 1॰45” LS dan 100॰27” BT - 101॰41” BT dengan luas 5764 ha (0,14\% dari luas Sumatera Barat) .

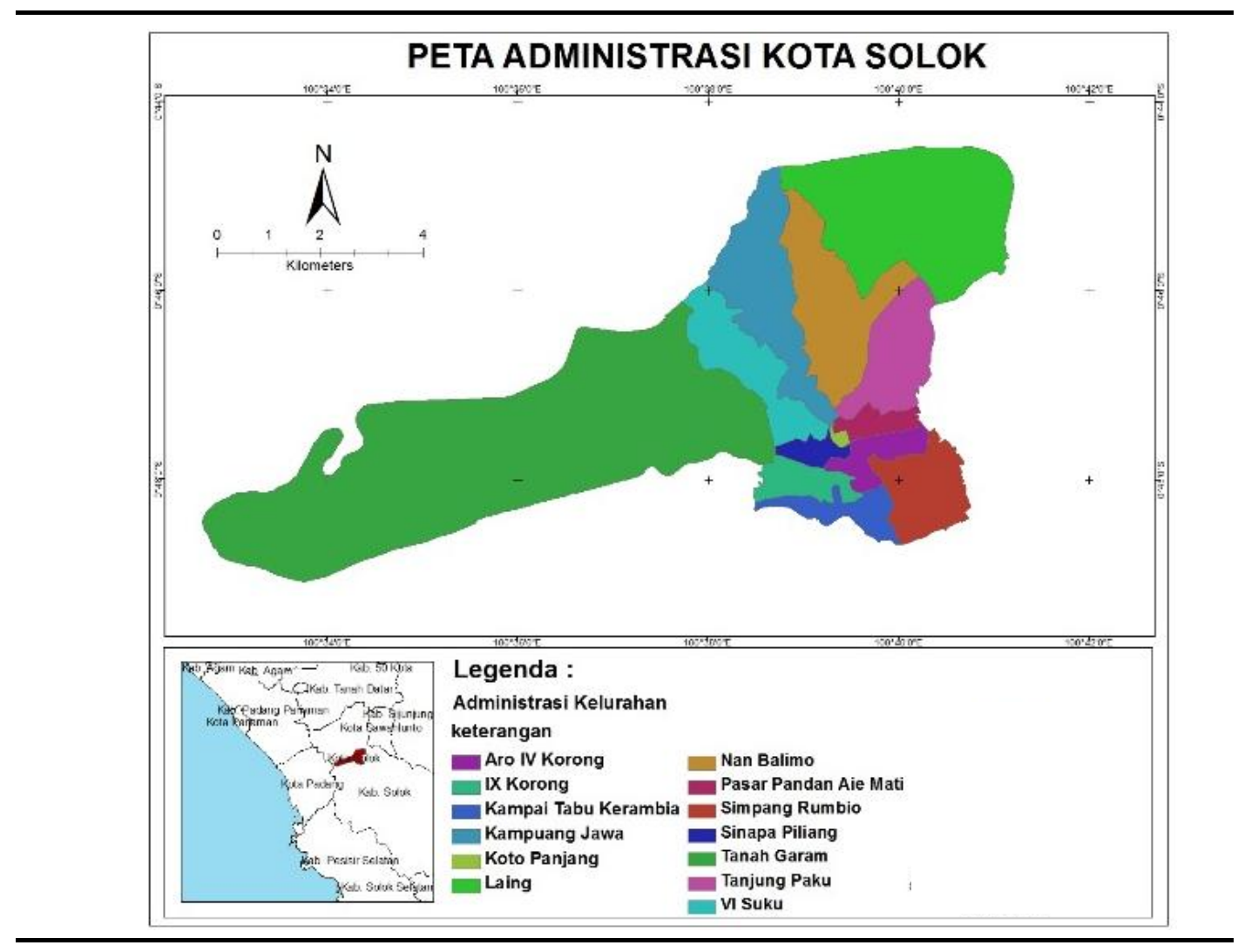

Gambar 1 Wilayah Administrasi Kota Solok 


\section{Jenis dan Sumber Data}

Data sekunder yang digunakanpada penelitian ini adalah peta penggunaan lahan, dan peta RTRW (masing-masing skala $1: 50$ 000), perundang-undangan dan peraturan-peraturan yang berhubungan dengan penelitian, dan penelitian terdahulu yang diperoleh dari beberapa instansi terkait baik pemerintah maupun swasta dan dari survei literatur. Data primer diperoleh dari pengamatan di lapangan dan wawancara langsung dengan stakeholders yang terkait dengan penelitian.

\section{Analisis Data}

\section{Identifikasi Perubahan Penggunaan Lahan Sawah}

Perubahan penggunaan lahan sawah dideteksi melalui proses tumpang tindih (overlay) antara peta penggunaan lahan tahun 2004 dan tahun 2014 dari Bappeda Kota Solok dengan menggunakan ArcGIS, hasil analisis ini digunakan untuk menunjukan konversi lahan di setiap kelurahan di Kota Solok. Ancaman konversi lahan sawah dilihat dengan mengoverlay peta penggunaan lahan 2014 dengan peta pola ruang pada RTRW Kota Solok

\section{Tingkat Perkembangan Wilayah}

Tingkat perkembangan wilayah dianalisis dengan analisis skalogram. Menurut Blakeley dan Bradshaw (2002) dalam Panuju dan Rustiadi (2013), analisis hierarki merupakan salah satu teknik analisis yang dapat digunakan untuk membangun indikator struktur perekonomian suatu wilayah.Metode skalogram untuk mengurutkan dan merangking wilayah atau kawasan pemukiman dan juga fasilitas. Variabel-variabel yang digunakan ditunjukan oleh Tabel 1.

Tabel 1 Variabel yang Digunakan pada Analisis Skalogram

\begin{tabular}{ll}
\hline Kelompok Indeks & Variabel yang digunakan \\
\hline Fasilitas Pendidikan & Jumlah TK \\
& Jumlah SD \\
& Jumlah SLTP \\
& Jumlah SMU \\
& Jumlah SMK \\
& Jumlah Akademi/PT \\
& Jumlah Madrasah \\
\hline Fasilitas Kesehatan & Jumlah Rumah Sakit \\
& Jumlah Puskesmas \\
& Jumlah Balai Pengobatan \\
& Jumlah Apotek \\
\hline Fasilitas Ekonomi & Jumlah pasar dan pertokoan \\
& Jumlah Bank Umum \\
& Jumlah BPR \\
\hline Fasilitas Sosial & Jumlah Koperasi \\
\hline Jarak ke fasilitas Pendidikan & Jumlah Masjid \\
& Jarak ke TK terdekat \\
& Jarak ke SLTP terdekat \\
& Jarak ke SMU terdekat \\
\hline Jarak ke fasilitas Ekonomi & Jarak ke SMK terdekat \\
\hline & Jarak pertokoan terdekat \\
& Jarak pasar terdekat \\
\hline
\end{tabular}




\begin{tabular}{ll}
\hline Jarak ke fasilitas Pemerintahan & $\begin{array}{l}\text { Jarak ke Kecamatan } \\
\text { Jarak ke Balaikota }\end{array}$
\end{tabular}

\section{Analisis Faktor-Faktor Penyebab Konversi Lahan Sawah}

Untuk mmengetahui faktor-faktor yang menyebabkan konversi lahan sawah menjadi nonpertanian di kota Solok dapat dilakukan dengan analisis regresi bertatar (stepwise regression analysis) dengan menggunakan software Minitab 16. Variabel yang digunakan dalam analisis ini ditunukan Tabel 2.

Tabel 2 Variabel-Variabel dalam Analisis Regresi Stepwise

\begin{tabular}{ll}
\hline Variabel Tujuan (Y) & Variabel Penduga (X) \\
\hline Luas lahan sawah & Perubahan kepadataan penduduk 2004-2014 (X1) \\
yang di konversi & Selisih Penerimaan PPBB 2004-2014 (X2) \\
$2004-2014(\mathrm{Y})$ & Perubahan jumlah fasilitas kesehatan 2004-2014 (X3) \\
& Perubahan jumlah fasilitas pendidikan 2004-2014 (X4) \\
& Selisish pengurusan hak tanah (X5) \\
& Alokasi industiri dalam pola ruang (X6) \\
& Alokasi pemukiman kepadatan rendah dalam pola ruang (X7) \\
& Alokasi pemukiman kepadatan sedang dalam pola ruang (X8) \\
& Alokasi pemukiman kepadatan tinngi dalam pola ruang (X9) \\
& Alokasi peribadatan dalam pola ruang (X10) \\
& Alokasi perdagangan dan jasa dalam pola ruang (X11) \\
& Alokasi pendidikan dalam pola ruang (X12) \\
& Alokasi perkantoran dalam pola ruang (X13) \\
& Alokasi kesehatan dalam pola ruang (X14) \\
& Alokasi sawah dalam pola ruang (X15) \\
\hline
\end{tabular}

Model regresi memiliki variabel terikat $(\mathrm{Y})$ dan variabel bebas $(\mathrm{X})$, variabel bebas digunakan untuk memprediksi variabel bebas dalam penelitian. Kedua variabel dihubungkan dengan persamaan :

$$
Y=\beta_{0}+\beta_{1} X_{1}+\beta_{2} X_{1}+\beta_{3} X_{3}+\beta_{4} X_{4}+\ldots+\beta_{i} X_{i}+\varepsilon
$$

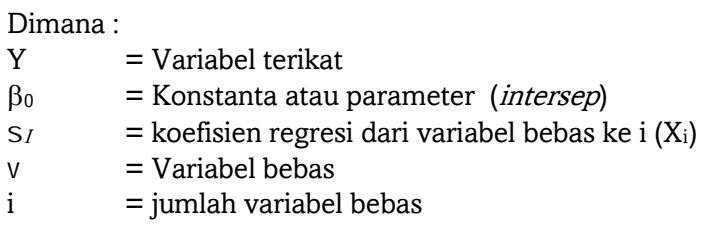

\section{Arahan Kebijakan Pengendalian Konversi Lahan Sawah}

Arahan pengendalian alih fungsi lahan berdasarkan faktor-faktor yang mempengaruhi konversi lahan sawah dengan tiga skenario untuk arahan pengendalian konversi lahan yaitu skenario optimis, moderat dan pesimis. Analisis deskriptif untuk membuat arahan pengendalian konversi lahan sawah dengan mengintervensi faktor-faktor yang mempengaruhi konversi lahan sawah di Kota Solok sesuai dengan hasil cek lapangan. Perumusan arahan pengendalian konversi lahan sawah dilakukan menggunakan analisis deskriptif kualitatif. Saili dan Purwadio (2012) menggunaka analisis deskriptif kualitatif dengan expert judgement dalam merumuskan pengendalian alih fungsi lahan pertanian menjadi perkebunan sawit di Kabupaten Siak yang sesuai dengan karakteristik yang ada. 
Pengendalian Konversi

Lahan

\section{HASIL DAN PEMBAHASAN}

\section{Identifikasi Perubahan Penggunaan Lahan Sawah di Kota Solok}

Kebutuhan akan lahan untuk kegiatan nonpertanian semakin meningkat seiring dengan pertumbuhan suatu wilayah dan peningkatan jumlah penduduk. Hal ini menyebabkan terjadinya perubahan penggunaan lahan terutama lahan sawah. Perubahan penggunaan lahan dapat diidentifikasi dengan mengoverlay peta pennggunaan lahan pada dua titik tahun yaitu peta penggunaan lahan 2004 dan 2014. Ruswandi et al. (2007) mengidentifikasi perubahan penggunaan lahan dengan pada dua titik tahun dengan cara mengurangi luas masing-masing penggunaan lahan pada kedua titik tahun tersebut.

Penggunaan lahan untuk sawah pada tahun 2004 seluas 1003,55 ha turun menjadi 971,27 ha atau sebesar 3,26\% pada tahun 2014. Penurunan luas areal ini juga terjadi pada penggunaan lahan kolam dari 2,81 ha menjadi 2,34 ha (16,73\%), hutan dari 2619,75 ha menjadi 2465 ha (5,89\%), RTH dari 1544,84 ha menjadi 1494 ha (3,26\%). Penurunan penggunaan lahan tersebut diikuti oleh peningkatan penggunaan lahan lainnya seperti perkebunan $(63,80 \%)$, perkantoran $(22,6 \%)$, pertambangan $(19,47 \%)$, pemukiman $(14,75 \%)$. Konversi lahan sawah terbanyak terjadi di Kecamatan Lubuk Sikarah sebesar 27,01 ha atau 83,67\% dari konversi sawah secara keseluruhan. Lahan Sawah di Kelurahan Tanah Garam telah terkonversi seluas 11,75 ha atau $34 \%$ dari luas konversi lahan sawah total. Konversi Lahan sawah di Tanah Garam tinggi karena luas lahan sawah di kelurahan tersebut lebih besar dari kelurahan lainnya. Sebaran lahan sawah tahun 2004 dan 2014 ditunjukan pada Gambar 2.
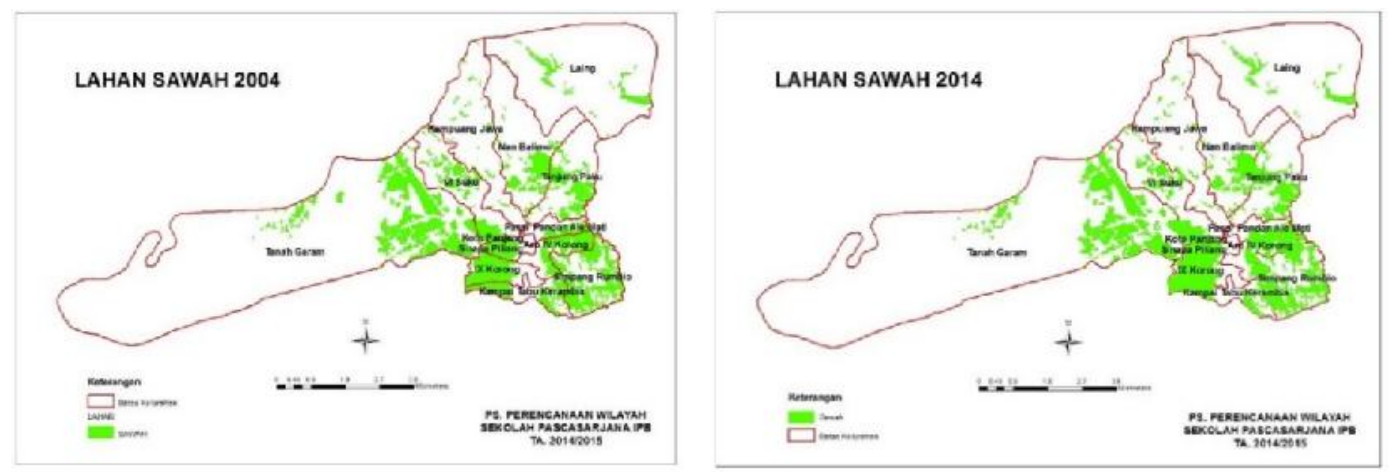

Gambar 2 Sebaran Sawah 2004 dan 2014

Tabel 3 menunjukan bahwa konversi lahan sawah telah terjadi hampir di seluruh kelurahan di Kota Solok kecuali kelurahan Sinapa Piliang. Kelurahan Sinapa Piliang Kecamatan Lubuk Sikarah cenderung tidak terjadi konversi lahan sawah. Lahan sawah di kelurahan Sinapa Piliang merupakan lahan sawah dengan irigasi teknis dengan produktifitas dan indeks pertanaman yang cukup tinggi, dimana produktifitas padi di daerah ini diatas rata-rata Kota Solok dan indeks pertanaman diatas 2,5. 
Tabel 3 Perubahan Penggunaan Lahan Sawah Kota Solok 2004-2014

\begin{tabular}{llrrr}
\hline \multirow{2}{*}{ No } & \multicolumn{1}{c}{ Kelurahan } & \multicolumn{2}{c}{$\begin{array}{c}\text { Pengunaan Lahan } \\
\text { Sawah (ha) }\end{array}$} & \multicolumn{1}{c}{$\begin{array}{c}\text { Konversi } \\
\text { Sawah }\end{array}$} \\
\cline { 3 - 4 } & & 2004 & 2014 & \multicolumn{1}{c}{ (ha) } \\
\hline I & Lubuk Sikarah & 764,82 & 737,81 & 27,01 \\
1 & Tanah Garam & 291,30 & 279,55 & 11,75 \\
2 & VI Suku & 83,49 & 78,40 & 5,09 \\
3 & Sinapa Piliang & 38,60 & 38,61 & 0,00 \\
4 & IX Korong & 76,83 & 76,40 & 0,43 \\
5 & Aro IV Korong & 69,91 & 68,45 & 1,46 \\
6 & Kampai Tabu Karambia & 64,97 & 62,13 & 2,84 \\
7 & Simpang Rumbio & 139,73 & 134,29 & 5,44 \\
\hline II & Tanjung Harapan & 238,73 & 233,45 & 5,27 \\
8 & Koto Panjang & 0,00 & 0,00 & 0,00 \\
9 & Pasar Pandan Aie Mati & 25,41 & 24,24 & 0,90 \\
10 & Kampung Jawa & 18,41 & 17,41 & 1,00 \\
\hline 11 & Tanjung Paku & 82,80 & 81,34 & 1,46 \\
12 & Nan Balimo & 66,40 & 65,15 & 1,25 \\
13 & Laing & 45,98 & 45,32 & 0,66 \\
\hline & Jumlah & 1003,55 & 971,29 & 32,28 \\
\hline
\end{tabular}

Rencana Tata Ruang Wilayah (RTRW) Kota Solok tahun 2012 - 2031 mengalokasikan penggunaan lahan sawah seluas 490,06 ha. Pengalokasian lahan sawah pada peta Pola Ruang sebesar 567,69 ha.Tabel 4 menunjukan bahwa ancaman konversi lahan sawah tidak ada di kelurahan Sinapa Piliang, disini terlihat pemerintah Kota Solok ingin mempertahankan sawah di kelurahan Sinapa Piliang.

Tabel 4 Ancaman Konversi Lahan Sawah di Kota Solok Berdasarkan Pola Ruang

\begin{tabular}{llrrr}
\hline No & \multicolumn{1}{c}{ Kelurahan } & $\begin{array}{c}\text { Alokasi Lahan Sawah } \\
\text { (ha) }\end{array}$ & $\begin{array}{c}\text { Lahan Sawah 2014 } \\
\text { (ha) }\end{array}$ & $\begin{array}{c}\text { Ancaman Konversi } \\
\text { Sawah (ha) }\end{array}$ \\
\hline 1 & Nan Balimo & 0,00 & 65,15 & 65,15 \\
2 & Simpang & & & 116,12 \\
& Rumbio & 18,17 & 134,29 & 13,34 \\
3 & Kampuang Jawa & 4,07 & 17,41 & 60,73 \\
4 & Tanjung Paku & 20,61 & 81,34 & 32,28 \\
5 & KTK & 29,85 & 62,13 & 10,80 \\
6 & PPA & 13,44 & 24,24 & 12,83 \\
7 & Laing & 32,49 & 45,32 & 17,98 \\
8 & Aro IV Korong & 50,47 & 68,45 & 17,88 \\
9 & VI Suku & 60,52 & 78,40 & 50,39 \\
10 & Tanah Garam & 229,16 & 279,55 & 6,10 \\
11 & IX Korong & 70,30 & 76,40 & 0,00 \\
\hline 12 & Sinapa Piliang & 38,61 & 38,61 & 403,60 \\
\hline Jumlah & & 567,69 & 971,29 & \\
\hline
\end{tabular}

Peluang terjadinya konversi lahan sawah di Kota Solok apabila dibandingkan antar jumlah lahan sawah di Kota Solok pada tahun 2014 dengan Pola Ruang Kota Solok yang terdapat dalam RTRW Kota Solok 2012 - 2031 sebesar 403,60 ha atau 41,55\% luas lahan sawah yang ada berpotensi untuk dikonversi. Berdasarkan tabel diatas dapat dilihat bahwa lahan sawah secara keseluruhan berpotensi untuk dikonversi. Lahan Sawah di kelurahan Nan Balimo berpotensi untuk dikonversi semuanya dimana pada tahun 2014 lahan sawah di Kelurahan Nan Balimo adalah 65,15 ha sedangkan pada pola ruang Kota Solok lahan sawah di Kelurahan Nan Balimo sudah tidak ada lagi. Potensi terjadinya konversi lahan sawah terbesar kedua di Kelurahan Simpang Rumbio yaitu 86,47\% diikuti oleh kelurahan Kampung 
Pengendalian Konversi

Lahan

Jawa dengan luas 13,34 ha (76,62\%), Tanjung Paku dengan luas 60,73 ha (74,66\%), Kampai Tabu Karambia (KTK) dengan luas 32,28 ha (51,96\%), Pasar Pandan Air Mati (PPA) dengan luas 10,80 ha $(44,55 \%)$, Laing dengan luas 12,83 ha $(28,31 \%)$, Aro IV Korong dengan luas 17,98 ha $(26,27 \%)$, VI Suku 17,88 ha $(22,81 \%)$, Tanah Garam 50,39 ha $(18,03 \%)$, dan IX Korong dengan luas 6,10 ha $(7,98 \%)$. Peluang konversi lahan tidak terdapat di Kelurahan Sinapa Piliang dimana luas lahan sawah di kelurahan ini tetap dipertahankan yaitu dengan luas 38,61 ha.

\section{Tingkat Perkembangan Wilayah Kota Solok}

Tingkat perkembangan wilayah di suatu wilayah dapat dianalisis dengan skalogram. Menurut Blakeley dan Bradshaw (2002) dalam Panuju dan Rustiadi (2013), Analisis hierarki merupakan salah satu teknik analisis yang dapat digunakan untuk membangun indikator struktur perekonomian suatu wilayah. Namun demikian pada awalnya metode yang digunakan sangat kualitatif. Fasilitas tidak diitinjau dari kuantitas maupun kemudahan untuk mengaksesnya. Metode yang digunakan untuk menentukan tingkat Perkembangan wilayah salah satunya adalah metode skalogram yang digunakan untuk mengurutkan dan merangking wilayah atau kawasan dengan melihat jumlah fasilitas yang dimiliki dan jarak ke fasilitas tersebut.

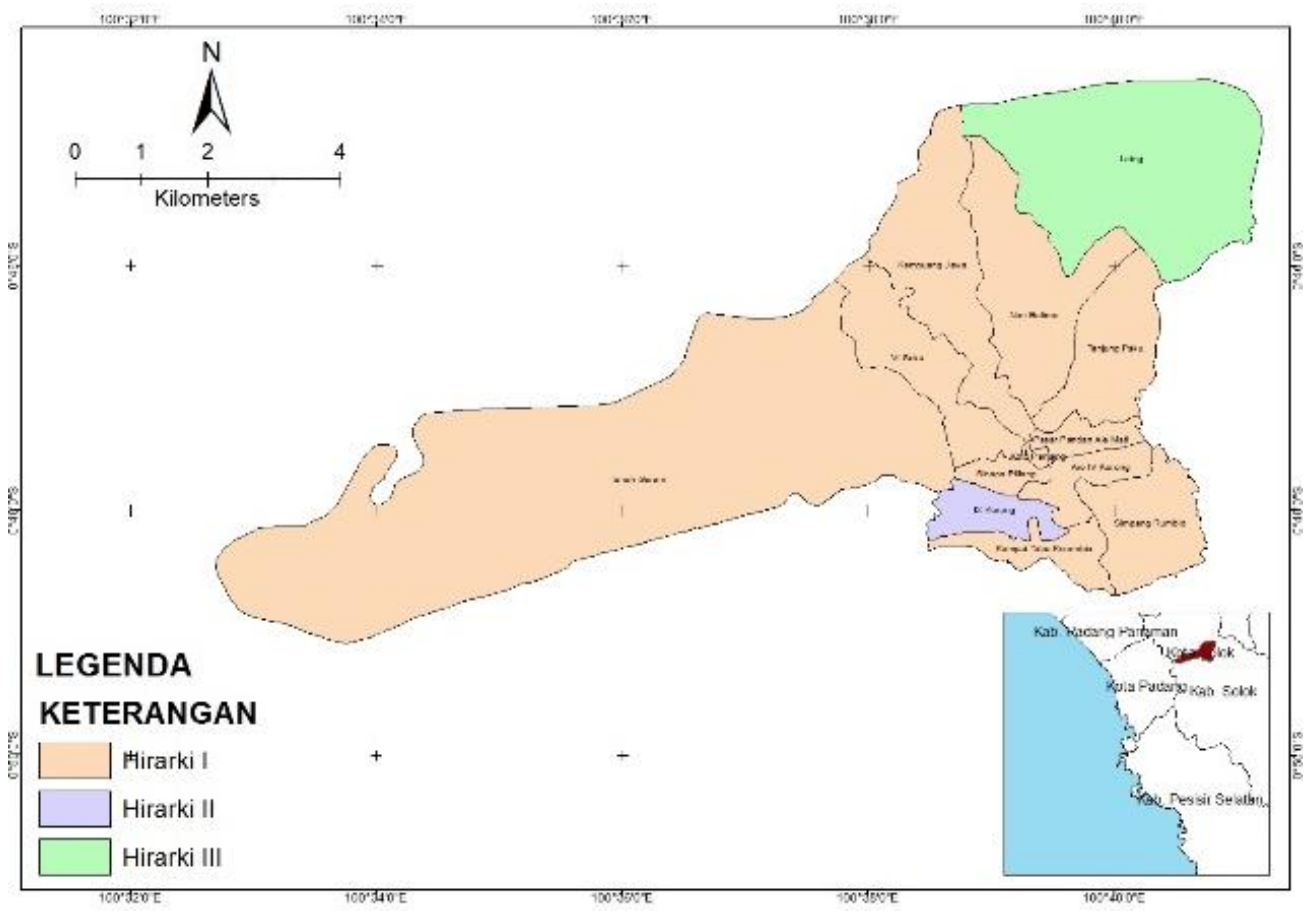

Gambar 3 Hirarki Wilayah Kota Solok 
Menurut Sitorus et al. (2009) tingkat perkembangan wilayah dinyatakan dalam bentuk Hirarki, yaitu Hirarki I, Hirarki II, dan Hirarki III, dimana kemajuan pembangunan di suatu wilayah sejalan dengan peningkatan jumlah penduduk dan akan selalu diiringi dengan meningkatnya standar kualitas dan kuantias kebutuhan hidup dan peningkatan kebutuhan ketersediaan fasilitas yang menyebabkan terjadinya perubahan penggunaan lahan. Perkembangan suatu wilayah dilihat dari hierarki suatu wilayah tersebut. Semakin tinggi hierarki suatu wilayah kecenderungan perubahan penggunaan lahan semakin kecil. Jenis penggunaan lahan dominan di wilayah berhierarki tinggi adalah lahan terbangun untuk berbagai aktivitas ekonomi. Hasil penelitian Sitorus et al. (2012) menunjukkan bahwa penggunaan lahan terbangun mengalami peningkatan cukup siginifikan terkait dengan pembangunan fasilitas pendidikan, kawasan industri, pemukiman tidak teratur, dan pemukiman teratur.

Perkembangan wilayah dengan analisis skalogram dilakukan pada semua kelurahan di Kota Solok untuk melihat tingkat perkembangan wilayah disetiap kelurahan tersebut. Dari hasil analisis skalogram yang telah dilakukan maka diperoleh kelurahan yang memiliki Hirarki I, Hirarki II dan Hirarki II. Kelurahan dengan Hirarki I adalah Kelurahan Tanah Garam, VI Suku, KTK, Sinapa Piliang, Aro IV Korong, Simpang Rumbio, Koto Panjang, PPA, Tanjung Paku, Nan Balimo, dan Kampung Jawa, kelurahan dengan Hirarki II adalah Kelurahan IX korong dan Kelurahan dengan Hirarki III adalah Kelurahan Laing (Gambar 3). Menurut Barus, et al. (2012) bahwa ancaman konversi lahan sawah ke penggunaan nonsawah sebagai damak semakin intensifnya pembangunan pemukiman dan jaringan infrastruktur, akan mengancam keberlanjutan lahan untuk produksi pangan tersebut.

Apabila dibandingkan Perubahan Penggunaan Lahan Sawah Kota Solok 2004-2014 dengan Hirarki Wilayah Kota Solok maka daat dilihat bahwa konversi lahan sawah didominasi oleh wilayah Hirarki I, sedangkan konversi lahan sawah di wilayah Hirarki II yaitu Kelurahan IX Korong hanya 0,43 ha atau 1,33\% dari luas lahan sawah yang dikonversi. Luas konversi lahan sawah di wilayah Hirarki III yaitu Kelurahan laing sebesar 0,66 atau hanya $2,04 \%$ dari luas lahan sawah yang telah dikonversi.

\section{Faktor-Faktor yang Mempengaruhi Konversi Lahan Sawah di Kota Solok}

Faktor-faktor yang mempengaruhi konversi lahan sawah dianalisis dengan menggunakan regresi linear berganda dengan metode regresi bertatar (stepwise) dengan menggunakan software Minitab 16. Pada metode stepwise pemilihan variabel yang pertama kali dimasukan ke dalam model didasarkan pada variabel bebas yang memiliki korelasi terbesar dengan variabel terikat. Tahap selanjutnya adalah memasukan variabel bebas yang memiliki korelasi terbesar kedua dengan variabel terikat. Tahap ini diulang terus hingga semua variabel masuk kedalam model, untuk memperoleh model terbaik maka dilakukan analisis regresi bertatar (stepwise). Sitorus et al. (2009) menyatakan prinsip dasar analisis bertatar adalah dengan mengurangi banyaknya variabel satu demi satu sampai diperoleh persamaan terbaik.

Analisis Regresi stepwise yang telah dilakukan dengan menggunakan minitab 16 maka ada tujuh variabel bebas yang berpengaruh nyata terhadap variabel terikat yaitu X2 (penerimaan PBB), X5 (pengurusan hak atas tanah), X6 (Alokasi industri pada Pola Ruang), X7 (Alokasi pemukiman rendah pada Pola Ruang), X9 (Alokasi pemukiman tinggi pada Pola Ruang), X10 (Alokasi lahan untuk peribadatan pada Pola Ruang), dan X15 (Alokasi sawah pada Pola Ruang) dengan taraf nyata $(\alpha=0,05)$. Hasil analisis regresi bertatar (stepwise regression) ditunjukan oleh Tabel 5.

Dari hasil analisis regresi bertatar diketahui bahwa ada tujuh faktor yang mempengaruhi terjadinya konversi lahan sawah di Kota Solok. Faktor-faktor yang berpengaruh sangat nyata terhadap konversi lahan sawah di Kota Solok adalah Pajak Bumi 
Pengendalian Konversi

Lahan

dan Bangunan (PBB), Hak atas Tanah, alokasi industri pada Pola Ruang, alokasi pemukiman kepadatan rendah pada Pola Ruang, alokasi pemukiman kepadatan tinggi pada Pola Ruang, alokasi peribadatan pada Pola Ruang, dan alokasi sawah pada Pola Ruang. Penyusunan arahan pengendalian konversi lahan sawah di Kota Solok didasarkan pada faktor-faktor yang mempengaruhi konversi lahan sawah tersebut dengan mempertimbangkan kondisi dan karakteristik dari Kota Solok.

Tabel 5 Hasil Stewise Regression Analysis

\begin{tabular}{|c|c|c|c|c|c|c|c|}
\hline Step & 1 & 2 & 3 & 4 & 5 & 6 & 7 \\
\hline Koefisien & 2,483 & 2,483 & 2,483 & 2,483 & 2,483 & 2,483 & 2,483 \\
\hline $\mathrm{X} 15$ & 2,73 & 2,13 & 2,18 & 2,10 & 1,45 & 1,24 & 1,430 \\
\hline T-Value & 4,96 & 5,51 & 7,31 & 9,49 & 4,81 & 10,19 & 25,74 \\
\hline P-Value & 0,000 & 0,000 & 0,000 & 0,000 & 0,002 & 0.000 & 0,000 \\
\hline X9 & & 1,558 & 1,199 & 1,378 & 1,529 & 1,663 & 1,596 \\
\hline T-Value & - & 4,03 & 3,70 & 5,62 & 7,76 & 20,88 & 49,59 \\
\hline P-Value & & 0,02 & 0,05 & 0,000 & 0,000 & 0,000 & 0,000 \\
\hline $\mathrm{X} 10$ & & & 0,844 & 1,214 & 1,325 & 1,608 & 1,591 \\
\hline T-Value & - & - & 2,80 & 4,79 & 6,65 & 17,95 & 46,66 \\
\hline P-Value & & & 0,021 & 0,001 & 0,000 & 0,000 & 0,000 \\
\hline $\mathrm{X} 7$ & & & & $-0,75$ & $-1,60$ & $-1,69$ & $-1,474$ \\
\hline T-Value & - & - & - & $-2,96$ & $-4,18$ & $-11,29$ & $-21,89$ \\
\hline P-Value & & & & 0,018 & 0,004 & 0,000 & 0,000 \\
\hline $\mathrm{X} 6$ & & & & & 1,03 & 1,23 & 1,065 \\
\hline T-Value & - & - & - & - & 2,57 & 7,69 & 16,08 \\
\hline P-Value & & & & & 0,037 & 0,000 & 0,000 \\
\hline $\mathrm{X} 2$ & & & & & & $-0,528$ & $-0,527$ \\
\hline T-Value & - & - & - & - & - & $-6,33$ & $-16,67$ \\
\hline P-Value & & & & & & 0,001 & 0,000 \\
\hline X5 & - & - & - & - & - & & 0.185 \\
\hline T-Value & & & & & & & 6,06 \\
\hline P-Value & & & & & & & 0,002 \\
\hline S & 1,91 & 1,24 & 0,953 & 0,698 & 0,535 & 0,209 & 0,079 \\
\hline R-Square & 69,07 & 88,20 & 93,70 & 96,99 & 98,45 & 99,80 & 99,98 \\
\hline $\begin{array}{l}\text { R-Square } \\
\text { (Adj) }\end{array}$ & 66,26 & 85,84 & 91,60 & 95,49 & 97,35 & 99,60 & 99,94 \\
\hline
\end{tabular}

\section{Arahan Kebijakan Pengendalian Alih Fungsi Lahan Sawah di Kota Solok}

Arahan pengendalian alih fungsi lahan diperoleh menggunakan hasil analisis faktorfaktor yang mempengaruhi konversi lahan sawah di Kota Solok dengan membuat skenario arahan pengendalian konversi lahan sawah di Kota Solok yaitu skenario optimis, moderat dan pesimis. Analisis deskriptif untuk membuat arahan pengendalian konversi lahan sawah dengan mengintervensi faktor-faktor yang mempengaruhi konversi lahan sawah di Kota Solok sesuai dengan hasil cek lapangan. Perumusan arahan pengendalian konversi lahan sawah dilakukan menggunakan analisis deskriptif kualitatif. Saili dan Purwadio (2012) menggunaka analisis deskriptif kualitatif dalam merumuskan pengendalian alih fungsi lahan pertanian menjadi perkebunan sawit di Kabupaten Siak. Analisis kualitatif digunakan untuk mengetahui karakteristik alih fungsi lahan, faktor-faktor yang penyebab alih fungsi kawasan pertanian lahan sawah di Kabupaten Siak, dampak alih fungsi kawasan dan pengendalian alih fungsi lahan. 


\section{Skenario Pesimis}

Pada skenario pesimis Pajak Bumi dan Bangunan dinaikan 20\%, Masyarakat yang mengurus hak atas tanah berkurang sebanyak 3\%, Alokasi Industri pada Pola Ruang, Alokasi pemukiman kepadatan tinggi, Alokasi Peribadatan pada Pola Ruang diturunkan masingmasingnya $10 \%, 5 \%$ dan $0,40 \%$. Alokasi pemukiman kepadatan rendah dinaikan $5 \%$ sedangkan Alokasi lahan sawah tetap. Intervensi tersebut diharapkan dapat menurunkan konversi lahan $10,08 \%$ atau 3,25 ha menjadi 29,03 ha dari luas konversi tanpa adanya intervensi 32,2 ha. Skenario moderat dilakukan dengan harapan konversi lahan sawah dapat ditekan $25,81 \%$ atau 7,49 ha. Intervensi yang dilakukan dapat menurunkan konversi lahan sawah dari 32,28 ha menjadi 24,79 ha.

\section{Skenario Moderat}

Pada skenario moderat, intervensi yang dilakukan adalah menaikan Nilai Pajak Bumi dan Bangunan (PBB) dan Alokasi Pemukiman Kepadatan rendah masing-masing 30\% dan $15 \%$, mengurangi masyarakat yang mengurus hak atas tanah $5 \%$, dan menurunkan Alokasi Industri, dan Pemukiman Kepadatan Tinggi pada Pola Ruang masing-masing 15\%, dan Peribadatan pada Pola Ruang 0,60\% dan Alokasi sawah pada Pola Ruang tidak berubah.

\section{Skenario Optimis}

Skenario Optimis diterapkan dengan harapan konversi lahan sawah dapat ditekan $47,33 \%$ (11,73 ha) yaitu dari 32,28 ha menjadi 20,55 ha. Dengan skenario optimis maka konversi lahan sawah di Kota Solok bisa dikendalikan menjadi lebih baik.Intervensi yang dilakukan pada skenario optimis ini adalah dengan menaikkan nilai Pajak Bumi dan Bangunan (PBB) dan Alokasi Pemukiman Kepadatan Rendah massing-masing 40\% dan 25\%, mengurangi masyarakat yang mengurus hak atas tanah 7\%, mengurangi Alokasi Industri, Pemukiman Kepadatan Tinggi, dan Peribadatan masing-masing 20\%, 25\% dan 0,80\%, sedangkan Alokasi lahan Sawah pada Pola Ruang adalah tetap.

\section{Arahan Pengendalian Konversi Lahan Sawah}

Skenario yang cocok diterapkan di Kota Solok adalah Skenario Optimis, dimana diharapkan konversi lahan sawah dapat ditekan 47,33\%.Arahan Pengendalian Konversi Lahan Sawah di Kota Solok ditunjukan Tabel 6.

Konversi lahan sawah dapat dikendalikan dengan skenario optimis di Kota Solok yaitu dengan menaikkan Nilai Jual Objek Pajak (NJOP) untuk nonpertanian (pemukiman, pertokoan, perkantoran dan lain-lain) dan memberikan insentif berupa keringanan pajak bagi lahan sawah terutama lahan sawah yang produktif, membatasi pemberian izin pendirian bangunan pada lahan sawah, meningkatkan peran lembaga adat dan tokoh masyarakat serta penyuluh pertanian dalam mengendalikan konversi lahan sawah, melaksanakan UU nomor 41 tahun 2009 tentang LP2B, memperbaiki jaringan irigasi, menetapkan peraturan tentang zonasi Kota Solok dengan penetapan RDTR Kota Solok dan pemberian sanksi ada masyarakat yang mengkonversi lahan sawah yang telah ditetapkan sebagai lahan abadi pada LP2B.

Tabel 6 Arahan Pengendalian Konversi Lahan Sawah di Kota Solok

\begin{tabular}{lll}
\multicolumn{4}{c}{ Tabel $\mathbf{6}$ Arahan Pengendalian Konversi Lahan Sawah di Kota Solok } \\
\hline \multirow{2}{*}{ No } & $\begin{array}{l}\text { Faktor-FaktorPenyebab } \\
\text { Konversi Lahan Sawah }\end{array}$ & Arahan Pengendalian Konversi Lahan Sawah \\
\hline 1 & $\begin{array}{l}\text { Nilai Pajak Bumi dan } \\
\text { Bangunan (PBB) }\end{array}$ & $\begin{array}{l}\text { Menaikan NJOP untuk nonpertanian } \\
\text { Memberikan insentif berupa keringanan pajak } \\
\text { untuk lahan sawah }\end{array}$
\end{tabular}


Pengendalian Konversi

Lahan

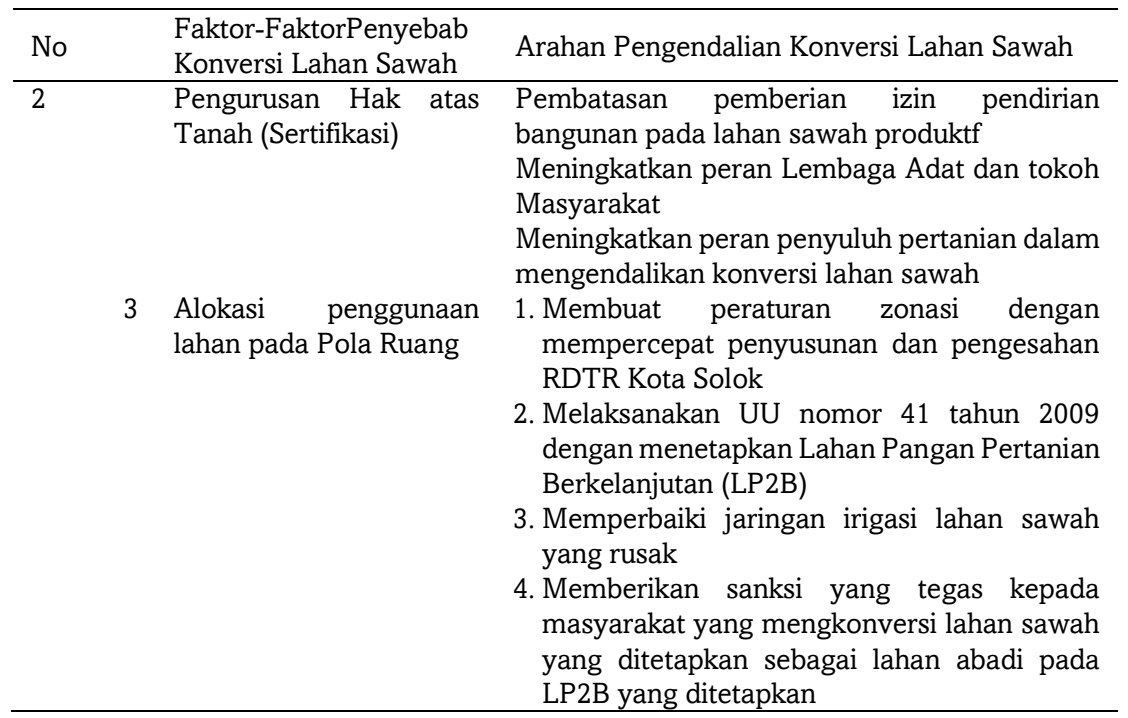

Penetapan Pajak tahun 2014 oleh Pemerintahan Kota Solok masih memakai data yang diberikan oleh KPP Pratama Solok karena pengalihan PBB dari pemerintah Pusat ke Pemerintah Daerah Kota Solok terhitung tanggal 1 Januari 2014, dengan menaikan Pajak Bumi Bangunan diharapkan konversi lahan sawah akan berkurang. Syahyuti (2011), usaha privatisasi tanah tetap diusahakan pemerintah melalui program sertifikasi tanah, dan sejak tahun 1960 telah diterbitkan 23,6 juta sertifikat tanah, namun sertifikasi ini merupakan penyebab lain semakin maraknya penjualan tanah yang nantinya berdampak merugikan. Umumnya lahan yang telah disertifikasi ini pada akhirnya akan mudah untuk dikonversi dari lahan sawah ke nonpertanian oleh pemilik lahan terutama pemilik yang mempunyai modal yang cukup besar. Pengendalian konversi lahan sawah ini dapat dilakukan dengan meningkatkatkan peran dari lembaga adat (KAN, LKAM dan Bundo Kanduang) yang ada di Kota Solok dan meningkatkan keterlibatan peran tokoh-tokoh masyarakat terutama tokohtokoh adat dan agama (Ninikmamak, Bundo Kanduang, dan Alim Ulama, penyuluh pertanian dalam mengendalikan konversi lahan sawah. Undang-Undang nomr 41 tahun 2009 di Kota Solok belum direalisasikan, dimana di Kota Solok belum ada Lahan Pertanian Pangan Berkelanjutan (LP2B) sehingga kemungkinan konversi lahan akan terus berlanjut tanpa ada lahan pertanian tanaman pangan yaitu sawah yang akan dipertahankan sebagai lahan untuk LP2B di Kota Solok. Disamping itu, untuk mengendalikan konversi lahan sawah di Kota Solok juga perlu diperbaiki saluran irigasi yang ada baik secara swadaya oleh kelembagaan tani dan masyarakat maupun oleh pemerintah sendiri. Jaringan irigasi yang baik diharapkan dapat meningkatkan produksi padi lahan sawah sehingga meningkatkan pendapatan petani padi di Kota Solok. Peningkatan pendapatan ini diharapkan dapat mengurangi keinginan masyarakat untuk mengkonversi lahan sawah yang dimilikinya.

\section{KESIMPULAN}

Berdasarkan Berdasarkan hasil analisis dan pembahasan yang dilakukan serta kaitannya dengan tujuan penelitian maka dapat disimpulkan hal-hal sebagai berikut: 
Konversi lahan sawah yang terjadi di Kota Solok dari tahun 2004 sampai 2014 32,28 ha atau 2,98\%. Sebagian besar kelurahan di Kota Solok berada pada wilayah berhierarki 1 kecuali kelurahan IX Korong dengan hierarki 2 dan kelurahan Laing dengan hierarki 3 dan konversi lahan sawah terjadi didominasi oleh kelurahan dengan hierarki 1.

Faktor-faktor yang meyebabkan konversi lahan sawah di Kota Solok adalah Pajak Bumi dan Bangunan (PBB), pengurusan hak atas tanah (sertifikasi tanah), alokasi lahan untuk industri pada Pola Ruang, alokasi lahan untuk pemukiman kepadatan rendah pada Pola Ruang, alokasi lahan untuk pemukiman kepadatan tinggi pada Pola Ruang, alokasi lahan untuk peribadatan pada Pola Ruang, dan alokasi lahan sawah pada Pola Ruang.

Arahan pengendalian konversi lahan sawah di Kota Solok dengan menerapkan skenario optimis yaitu dengan menaikan Nilai Jual Objek Pajak (NJOP) untuk lahan nonpertanian terutama lahan nonsawah, memberikan insentif berupa keringanan pajak pada lahan sawah, pembatasan izin pendirian bangunan pada lahan sawah dan tidak memberikan izin pendirian bangunan pada lahan sawah produktif, meningkatkan peran lembaga adat, tokoh masyarakat, penyuluh pertanian, pembangunan pemukiman keatas bukan kesamping, perbaikan dan peningkatan sarana peribadatan yang ada, realisasi Undang-Undang nomor 41 tahun 2009 tentang LP2B, dan memperbaiki jaringan irigasi yang ada serta menetapkan peraturan zonasi dengan mempercepat penyusunan dan penetapan RDTR Kota Solok.

\section{DAFTAR PUSTAKA}

[BPS] Badan Pusat Statistik Kota Solok. 2005. Kota Solok dalam Angka 2005. BPS Kota Solok. Solok

[BPS] Badan Pusat Statistik Kota Solok. 2015. Kota Solok dalam Angka 2015. BPS Kota Solok. Solok

Barus B, Panuju DR, Iman LS, Trisasongko BH, Gandasasmita K, Kusumo R. 2012. Pemetaan Potensi Konversi Lahan Sawah dalam Kaitan Lahan Pertanian Berkelanjutan dengan Analisis Spasial. Prosiding Tanah untuk Kehidupan yang Berkualitas. Seminar dan Kongres Nasional X Himpunan Ilmu Tanah Indonesia (HITI); Surakarta, Indonesia, 6 - 8 Desember 2011. Jurusan Ilmu Tanah Fakultas Pertanian UNS. Hal $554-561$.

Djajus E. 2009. Strategi Penanganan Krisis Sumberdaya Lahan untuk Mendukung Kedaulatan Pangan dan Energi di Kabupaten Lampung Selatan. Prosiding Semiloka Nasional : Strategi Penanganan Krisis Sumberdaya Lahan untuk Mendukung Kedaulatan Pangan dan Energi; Bogor, Indonesia, 23 - 23 Desember 2008 . Bogor. Departemen Ilmu Tanah dan Sumberdaya Lahan Fakultas Pertanian Institut Pertanian Bogor. Hal. $97-101$.

Hidayat AH, Hanafie U, Nurmelati S. 2012. Dampak Konversi Lahan Pertanian Bagi Taraf Hidup Petani di Kelurahan Landasan Ulin Barat Kecamatan Liang Anggang Kota Banjarbaru. Dikutip dari ejournal.unlam.ac.id. [18 Juni 2014]

Irawan B, Friyatno S. 2002. Dampak Konversi Lahan Sawah di Jawa terhadap Produksi Beras dan Kebijakan Pengendaliannya. Jurnal Sosial Ekonomi Pertanian dan Agribisnis 2(2), 79 - 95.

Iqbal M. 2007. Fenomena dan Strategi Kebijakan Pemerintah Daerah dalam Pengendalian Konversi Lahan Sawah di Propinsi Bali dan Nusa Tenggara Barat. Jurnal Analisis Kebijakan Pertanian 5(4), 287 - 303.

Panuju DR dan Rustiadi E. (2013). Teknik Analisis Perencanaan Pengembangan Wilayah. Departemen Ilmu Tanah dan Sumberdaya Lahan Fakultas Pertanian Institut Pertanian Bogor.

Ruswandi A, Rustiadi E, Mudikdjo K. (2007). Konversi Lahan Pertanian dan Dinamika Perubahan Penggunaan Lahan di Kawasan Bandung Utara. Jurnal Tanah dan Lingkungan. 9(2), 63 - 69.

Saili I dan Purwadio H. (2012). Pengendalian Alih Fungsi Lahan Pertanian Sawah menjadi Perkebunan Kelapa Sawit di Wilayah Kabupaten Siak-Riau. Jurnal Teknik Perencanaan Wilayah dan Kota 1(1), 1-3.

Santosa IGN, Adnyana GM, Dinata IK. (2011). Dampak Alih Fungsi Lahan Sawah terhadap Ketahanan Pangan Beras. Prosiding Nasional Budidaya Pertanian : Urgensi dan Strategi Pengendalian Alih Fungsi Lahan Pertanian; Bengkulu, Indonesia, 7 Juli 2011. Bengkulu. Universitas Bengkulu. Bengkulu. Hal. 1 - 11.

Sitorus SRP, Leonataris C, Panuju DR. (2012). Analisis Pola Perubahan Penggunaan Lahan dan Perkembangan Wilayah di Kota Bekasi, Provinsi Jawa Barat. Jurnal Tanah dan Lingkungan, 14 (1) : 21 - 28. 
131

Pengendalian Konversi

Lahan
Arahan Kebijakan

Syahyuti. (2011). Delandreformasi sebagai Gejala Anti Landreform di Indonesia : Karakter, Penyebab, dan Upaya Pengendaliannya. Jurnal Forum Penelitian Agro Ekonomi 29(2) : $67-8$

TATALOKA - VOLUME 18 NOMOR 2 - MEI 2016 - p ISSN 0852-7458 - e ISSN 2356-0266 